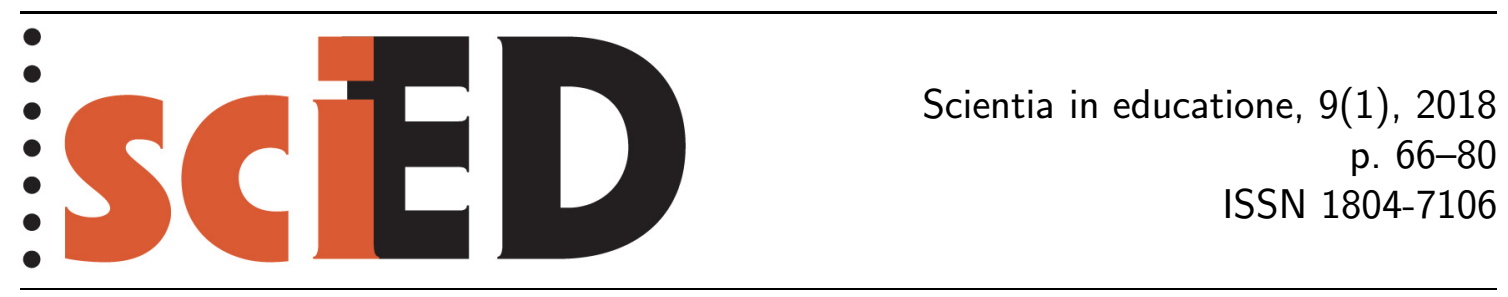

\title{
Vědecké myšlení a metakognitivní monitorování studentů učitelství pro 1. stupeň základní školy
}

\author{
Alena Nováková, Vlastimil Chytrý, Jaroslav Říčan
}

\begin{abstract}
Abstrakt
Výzkum popsaný v tomto článku je zaměřen na analýzu závislosti úrovně vědeckého myšlení a metakognitivního monitorování studentů učitelství pro 1. stupeň ZS̆. Hlavní dikce je směřována $\mathrm{k}$ využití Lawsonova testu vědeckého myšlení rozššřeného o sebeposuzovací škály, které lze využít jako indikátor metakognitivního monitorování. Na základě výsledků daného testu v porovnání s odpověd’mi na zmíněné škále byl vyhodnocen a analyzován index absolutní přesnosti (určuje míru přesnosti subjektivního odhadu výkonu v porovnání s objektivně prokázaným výkonem) a bias index (určuje míru jedincova sebepodceňování nebo sebenadhodnocování, tedy směr a velikost chyby v úsudku). Bylo analyzováno celkem 125 testů studentů učitelství s cílem zjistit vztah mezi výsledky v testu měřícího úroveň vědeckého myšlení a úrovní metakognitivního monitorování. Bylo zjištěno, že úroveň vědeckého myšlení studentů vykazuje v některých oblastech silnou korelaci se sebehodnocením respondenta (čím lepší byl výsledek jejich testu vědeckého myšlení, tím přesnější byli studenti v posouzení vlastního výkonu). V rámci studie byl také zaznamenán rozdíl v úrovni vědeckého myšlení mezi bývalými studenty gymnázia, kteří dosahovali v testu vyšších výsledků oproti studentům, kteři studovali jinou střední školu. U všech analyzovaných studentů se projevila tendence nadhodnocovat se, přičemž tento trend nesouvisí s druhem studované školy.
\end{abstract}

Klíčová slova: vědecké myšlení, metakognitivní monitorování, přírodovědné vzdělávání.

\section{Scientific Thinking and Metacognitive Monitoring of Students of Primary School Teaching}

\begin{abstract}
The research described in this article is focused on the analysis of the level of scientific thinking and the metacognitive monitoring of students of primary school teaching. The primary area of research is the use of the Lawson test of scientific reasoning extended by the self-evaluation scale, which can be used as an indicator of metacognitive monitoring. Based on the results of the given test, two indexes were computed: the absolute accuracy index (which determines the degree of accuracy of the subjective performance estimate compared to the objectively proven performance) and the bias index (which determines
\end{abstract}


the degree of the individual's underestimation or overestimation, i.e. the direction and size of errors in judgment). A total of 125 tests from student teachers were analyzed in order to establish the relationship between the results of the test of the level of scientific reasoning and the level of metacognitive monitoring. It has been found that students' level of scientific reasoning shows a strong correlation in some areas with the self-assessment of the respondent (the better were the results of their tests of scientific reasoning, the more accurate the students were in assessing their own performance). The study also noted a difference in the level of scientific reasoning among former grammar school students who achieved a higher test score than those who studied another high school. All analyzed students tended to overestimate themselves, this trend does not vary depending on the type of high school studied.

Key words: scientific reasoning, metacognitive monitoring, science education.

\section{VĚDECKÉ MYŠLENí A METAKOGNICE - DOVEDNOSTI 21. STOLETÍ}

Rychlý rozvoj technologií s sebou přináší i nové pracovní pozice, jež vyžadují specifické dovednosti, které by měly být rozvíjeny už od 1 . stupně základní školy. Často se v této souvislosti mluví o rozvoji dovedností pro 21. století (Osborne, 2013; Hilton, 2008; Hill, 2007; Gilbert, 2005). Mezi tyto dovednosti patř́i nejen metakognice, ale i vědecké myšlení, jež se uplatňuje zejména v rámci př́rodovědně orientovaných oborů a zahrnuje v sobě (podobně jako metakognitivní procesy) kritické uvažování, řešení problémů, rozhodování se a kreativitu (Jang, 2016; Bao \& Koenig, 2012). Pojetí výuky by tedy mělo být přizpůsobeno maximálnímu rozvoji těchto dovedností. Výsledky mezinárodního výzkumu TIMSS z roku 2015 sice ukazují, že se úroveň uvažování českých žáků v přrirodovědně zaměřených oblastech oproti poslednímu šetření zvýšila, stále je však tento sledovaný aspekt jejich slabinou (Tomášek, Basl \& Janoušková, 2016). Šetření PISA z roku 2015 zaměřené na přírodovědnou gramotnost, která je již podle své definice úzce spojena s vědeckým myšlením (dále jen VM), poukazuje na fakt, že za posledních devět let se výsledek českých žáků v tomto testu významně zhoršil (Blažek \& Příhodová, 2016). Na důležitost tohoto tématu poukazuje i řada publikací. Např. Janoušková a kol. (2014) navrhují na základě podrobné analýzy strukturu přírodovědné gramotnosti pro preprimární a rané primární vzdělávání, upozorňují na malé množství didaktických materiálů a nedostatečné proškolení samotných učitelů (Janoušková et al., 2014). Právě z tohoto důvodu jsme se zaměřili na zmíněné fenomény (vědecké myšlení a metakognitivní monitorování), a to zejména u budoucích učitelů pro 1. stupeň ZŠ, kteří budou svou následnou pedagogickou činností přímo ovlivňovat nastupující generace.

\section{VĚDECKÉ MYŠLENÍ}

Na VM existuje mnoho různých pohledů. Zimmerman (2007) chápe tento pojem jako proces vědeckého objevování projevující se bádáním, experimentováním, hodnocením výsledků a závěrečným usuzováním, které vede ke konceptuální změně nebo vědeckému poznání. Oproti tomu Bao a Koenig (2012) jej charakterizují jako „konkrétněji“ vymezené kritické myšlení, potažmo jako klíčový komponent kognitivních 
dovedností 21. století v kontextu přírodovědně a technicky zaměřených vědeckých disciplín. Jeho základním specifikem je, že při něm dochází k aplikaci metod a principů samotného bádání v situacích vyžadujících uvažování či řešení problémů (Kuhn \& Franklin, 2006). I přesto, že je toto myšlení explicitně zaměřeno na vědecké poznání, jež je výsledkem právě cílevědomého a systematického objevování (Kuhn, 2010), využívá VM množství obecně užívaných kognitivních operací, jako je indukce, dedukce, analogie, řešení problémů a kauzální uvažování (Holyoak \& Morrison, 2005).

Dejonckheere, Keere a Mestdagh (2009) jsou přesvědčeni o tom, že se nejedná pouze o záležitost vědců, nebot' VM můžeme pozorovat již u dětí předškolního věku. V tomto období jsou sice děti omezeny na určité stupně VM, kdy např́klad cítí rozdíl mezi tvrzením vygenerovaným lidskou myslí a vnější realitou, s níž může být toto tvrzení porovnáno, avšak nedokáží zatím tento poznatek plně využít (Kuhn \& Pearsall, 2000).

Autoři článku pohlíží na VM jako na způsob myšlení, který úzce souvisí s činností, při níž jedinec využívá vědecké metody a úspěšně řeší stanovené problémy. Takovou činností může být např́iklad prŕíprava, provedení a zhodnocení experimentu (Windschitl, 2004) v př́padě, že jsou dodrženy všechny náležitosti a jedná se o edukační experiment, nikoli pouhou demonstraci (viz např. Beneš, 1999; Trna, 2013; Beneš, Rusek \& Kudrna, 2015).

Lawsonův test VM umožňuje mapovat na základě logického myšlení schopnost jedince předpovědět výsledek připravovaného pokusu. Měří také schopnost práce s vnějšími podmínkami pokusu, jejich ovlivňování a stanovení očekávaných výsledků. V neposlední řadě testuje korelační myšlení a dovednost pracovat s poměrem a pravděpodobností. Lawsonův test bude podrobněji popsán v následujícím oddíle. Bao a Koenig (2012) uvádějí, že za nejvýznamnější atributy, které je nutné sledovat při testování VM, je možné považovat práci s proměnnými, pravděpodobností, poměry, korelací a dále také základní logické, induktivní, příčinné a hypoteticko-deduktivní uvažování.

\section{MĚŘENí VĚDECKÉHO MYŠLENÍ}

Vědecké myšlení lze hodnotit bud' na základě pozorování (zejména při řešení badatelsky orientovaného úkolu), prostřednictvím rozhovoru nebo měřením pomocí testové baterie.

Nejrozššřenějším testem pro měření VM je standardizovaný Lawsonův test vědeckého myšlení, který obsahuje 24 uzavřených otázek uspořádaných do dvojic (viz obr. 1). První z dvojice otázek je často doprovázena ilustrací dané situace, po zodpovězení následuje otázka, která vyžaduje zdůvodnění předchozí odpovědi. Úlohy v testu pokrývají sedm odlišných oblastí, a tak test postihuje velmi důležité výše zmíněné atributy. Tento test je určen pro studenty, kteří dokončují středoškolské vzdělávání, nebo již navštěvují vysokou školu (Lawson, 2000).

Lawsonův test $\mathrm{k}$ zjištování úrovně vědeckého myšlení využívají ve svých výzkumech např́ílad Coletta a Phillips (2005), Bao a kol. (2009b), Moore a Rubbo (2012) a Ding (2013). Moore, O’Donnell a Poirier (2012) využili Lawsonův test ke zkoumání účinnosti různých př́istupů, jež měly za cíl zvýšit úroveň VM.

Dalším testem měřícím úroveň VM je test iSTAR (Invenory for Scientific Thinking and Reasoning), který je vytvořen na základě výše zmíněného Lawsonova testu. Jedná se o celý soubor testových otázek různých obtížností, a proto jej lze využít 
3) Vpravo vidíte nákres dvou odměrných válců, které jsou naplněny vodou do stejné výšky. Válce mají stejné rozměry i tvar.

Na obrázku vpravo jsou znázorněny i dvě kuličky, jedna je skleněná, druhá je ocelová. Kuličky jsou stejně velké, ale ocelová kulička je daleko těžší než skleněná.

Když hodíme skleněnou kuličku do prvního válce, klesne ke dnu a voda vystoupá až k šesté rysce.

Pokud hodíme ocelovou kuličku do válce 2, voda vystoupá

a) na stejnou úroveň jako ve válci 1 .

b) výše než ve válci 1 .

c) níže než ve válci 1 .
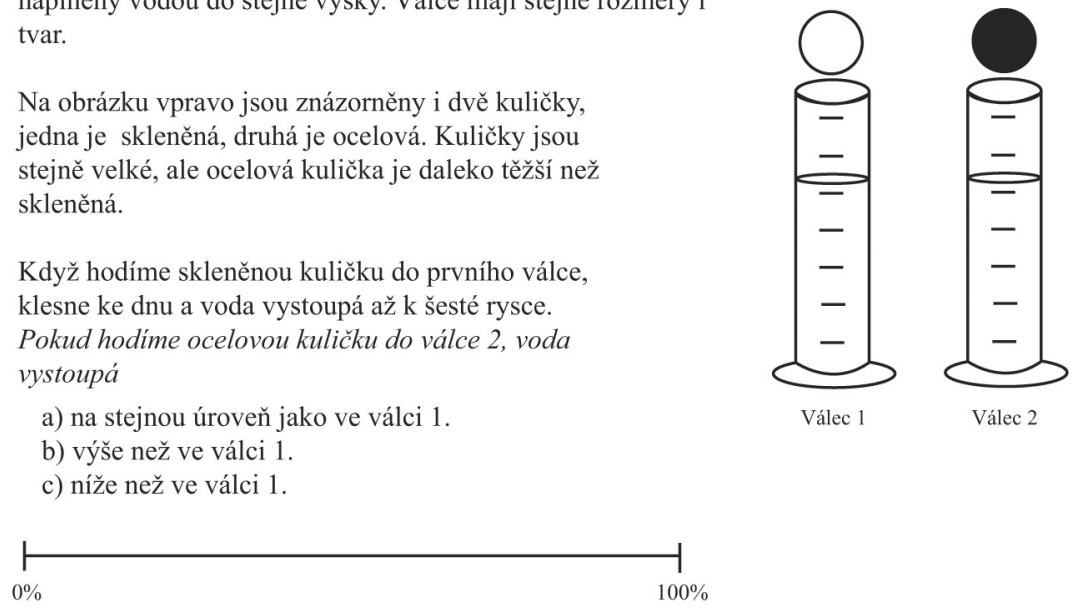

4) protože
a) ocelová kulička klesne rychleji
b) kuličky jsou vyrobeny $\mathrm{z}$ různých materiálů
c) ocelová kulička je těžší než skleněná
d) skleněná kulička vytváří menší tlak
e) kuličky jsou stejně velké

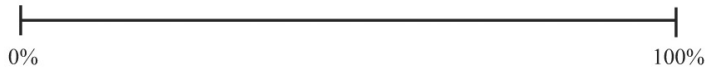

Obr. 1: Dvojice otázek Lawsonova testu (Lawson, 2000)

od testování VM žáků prvního stupně až po měření VM vysokoškolských studentů (Bao \& Koenig, 2012).

Nelze opomenout ani test Osborna a Ratcliffa (2002), jenž obsahuje položky, v nichž jsou žákům předložena fakta a s nimi i úsudky, $\mathrm{k}$ nimž došly na základě daných dat čtyři děti. Žákovým úkolem je pak následně určit, které z dětí uvažovalo správně.

Položky testující VM jsou obsaženy i v již zmiňovaných testech TIMSS a PISA.

\section{METAKOGNITIVNí MONITOROVÁNí}

Metakognitivní monitorování je procesuální ${ }^{1}$ složkou metakognice, která je dále tvořena předvídáním, plánováním a evaluací. Metakognitivní monitorování je možné chápat jako proces, v němž si jedinec uvědomuje kvalitu svého porozumění. Podle Winneho a Hadwina (1998) to je právě metakognitivní aspekt monitorování, který je nejvýznamnější složkou, jež nemusí ani u dospělých jedinců zdaleka dosahovat dostatečné úrovně.

Jedním z častých zpo̊sobů, jak zjištovat úroveň metakognitivního monitorování, je analyzovat míru postdikčních soudů jistoty správnosti odpovědi respondenta na konkrétní otázky (confidence judgements). Oproti predikčním soudům (judgements of learning), v nichž jedinec např. předpovídá svůj celkový testový „skór" předtím než uvidí vlastní test (nebo pracovní list), jsou tak postdikční soudy přesnější (Hacker, Bol, Horgan \& Rakow, 2008). Postdikční soudy se mohou týkat globálního odhadu ( „Kolik položek jsem správně vyřešil?“), nebo lokálního odhadu ( „Do jaké míry jsem si jistý, že jsem na tuto konkrétní položku odpověděl správně?"). Z důvodu, že lokální odhad vykazuje vyšší míru přesnosti, byly pro účely této stu-

\footnotetext{
${ }^{1}$ Druhou (obsahovou) složkou jsou metakognitivní znalosti.
} 
die použity právě lokální odhady (Nietfeld, Cao \& Osborne, 2005). Míru jistoty lze zaznamenat na ratingové škále (viz obr. 1).

Pomocí dat získaných z postdikčních soudů lze určit pět ${ }^{2}$ základních indexů. Pro účely této studie byl použit nejčastěji používaný ukazatel, tzv. absolutní přesnost ${ }^{3}$ (absolute accuracy), kterou můžeme definovat jako diskrepance mezi subjektivním soudem jistoty a skutečně prokázaným výkonem v dané úloze (Maki et al., 2005). Bias index odkazuje na míru zkreslení respondentova vnímání a lze z něj vyčíst, zda a do jaké míry se jedinec nadhodnocuje, nebo naopak podhodnocuje (Bol \& Hacker, 2012).

\section{CÍl vÝZKUMU}

Cílem výzkumu je analyzovat závislost úrovně VM a úrovně metakognitivního monitorování vysokoškolských studentů oboru učitelství pro 1. stupeň ZŠ v závislosti na studované střední škole. Výzkumy prokazují, že záměrnou intervencí badatelsky orientované výuky a metody problémového výkladu dochází k pozitivnímu ovlivňování vědeckého myšlení i metakognitivní rozvinutosti (Říčan \& Chytrý, 2016; Benford \& Lawson, 2001; Gerber, Cavallo \& Marek, 2001).

Celkem byly formulovány následující čtyři výzkumné otázky: i) Jaká je úroveň vědeckého myšlení studenti̊ učitelství pro 1. stupeň ZŠ?, ii) Jaká je spojitost mezi úrovní vědeckého myšlení a druhem studované střední školy?, iii) Jaká je úroveň hodnocení vlastního výkonu (metakognitivního monitorování) při řešení úloh testu vědeckého myšlení studenty?, iv) Jaká je spojitost mezi úrovní vědeckého myšlení a úrovní hodnocení vlastního výkonu při řešení úloh testu vědeckého myšlení studenty?

Tyto výzkumné otázky jsou později operacionalizovány na hypotézy, k nimž jsou formulovány příslušné nulové hypotézy dle odpovídajících testů využitých k samotné analýze dat.

\section{METODIKA VÝZKUMU A ZPŮSOB VYHODNOCENí ZÍSKANÝCH DAT}

Výzkumu se zúčastnili vysokoškolští studenti studující obor učitelství pro 1. stupeň ZŠ. Jednalo se o studenty různých ročníků prezenční formy studia. Na výzkumu participovalo celkem 125 studentů ( 7 mužů a 118 žen). Pro testování byl použit Lawsonův test vědeckého myšlení (Lawson, 2000) doplněný o soudy jistoty, které studenti zaznamenávali na ratingové škále (viz obr. 1). Test byl studentům rozdán v únoru roku 2017. Časová dotace na řešení testu činila půl hodiny. V testu se hodnotí na sebe navazující dvojice položek (úloha je vždy doprovázena další úlohou, která je zaměřena na zdi̊vodnění předchozí situace). Bod je přidělen každé z úloh pouze $\mathrm{v}$ př́padě, kdy jsou zodpovězeny obě úlohy správně. Takovýchto dvojic je v testu 11. Za nimi jsou zařazeny dvě úlohy, které na sebe nenavazují, přičemž za každou z nich je možné získat jeden bod.

\footnotetext{
${ }^{2}$ Index absolutní přesnosti (absolute accuracy index), index relativní přesnosti (relative accuracy index), index diskriminace (discrimination index), dále scatter index, jenž určuje poměr míry kalibračního úsudku u správně a chybně zodpovězených úloh a index zkreslení (bias index) (Schraw, 1998).

${ }^{3} \mathrm{~V}$ literatuře též jako tzv. kalibrační index (calibration index).
} 
Jak Moore a Rubb (2012) upozorňují, některé z položek staví na matematických konceptech, a proto lze tedy očekávat rozdíl ve výsledcích testu VM mezi studenty, kteří studovali na gymnáziu, a studenty, jež studovali jinou střední školu (v př́padě námi zkoumaných studentů se jednalo většinou o střední pedagogickou školu), a to se např́ílad projevilo u logického myšlení (Chytrý, 2015).

Inspirací pro princip aplikovat koncept metakognitivního monitorování byl již realizovaný výzkum Říčana (2016), který ve své publikaci rovněž detailně uvádí, jak je možné získaná data analyzovat. Respondenti měli možnost ke každé testové položce provést záznam od $0 \%$ („vůbec si správností své odpovědi nejsem jistý“) až po $100 \%$ (,jsem si správností své odpovědi absolutně jistý“). Na základě sebehodnocení a reálného výsledku jsme vypočítali index absolutní přesnosti a bias. Tyto indexy lze počítat jen za předpokladu, že položky hodnotíme pouze bud' jako správně, nebo jako špatně zodpovězené.

Index absolutní přesnosti lze vyjádřit pomocí vztahu $\frac{1}{N} \sum_{i=1}^{N}\left(C_{i}-p_{i}\right)^{2}$, kde $C_{i}$ je hodnota míry soudu jistoty (nabývá hodnot 0 - „vůbec si nejsem jistý" až 1 - ,jsem si úplně jistý"), $p_{i}$ př̀edstavuje výkon v dané položce (nabývá hodnot 0 - nesprávná odpověd’ nebo 1 - správná odpověd'). Výsledná absolutní přesnost se pohybuje v rozmezí od 0 do 1 . Hodnota 0 označuje nejvyšší míru přesnosti sebehodnocení. Například respondent, který u správně zodpovězené otázky označil, že si je správností své odpovědi úplně jistý, odpověděl s absolutní přesností 0 („nula“; stejná hodnota bude $\mathrm{v}$ případě, když u chybně označené odpovědi respondent označil, že si vůbec není jistý). Výsledná hodnota 1 naopak poukazuje na nejnižší míru přesnosti sebehodnocení. Označuje např́íklad respondenta, jenž u špatně zodpovězené otázky uvedl, že si je správností své odpovědi úplně jistý, či naopak toho, který u správně zodpovězené odpovědi napsal, že si správností své odpovědi vůbec jistý není. Jak je z př́kladu patrné, z výsledků absolutní přesnosti neurčíme, zda se jedinec při sebehodnocení nadhodnocuje, či naopak podhodnocuje. K tomu slouží následující ukazatel bias, který je dán vztahem $\frac{1}{N} \sum_{i=1}^{N}\left(C_{i}-p_{i}\right)$, kde $C_{i}$ je hodnota míry soudu jistoty, $p_{i}$ představuje výkon v dané položce. $\mathrm{K}$ výpočtu biasu se používá podobný vzorec, přičemž chybí jen umocnění, a tak může index nabývat hodnot od -1 do 1 . Kladné hodnoty výsledného indexu poukazují na nadhodnocování se, záporné pak na podhodnocování se (Bol \& Hacker, 2012).

Odpovědi na jednotlivé testové otázky je možné hodnotit pouze alternativně: 0 - student odpověděl chybně, 1 - student odpověděl správně. Pokud respondent na otázku neodpověděl, byl pro kódování použit prázdný znak. Tento zpơsob kódování umožňuje tuto interpretaci výsledků: aritmetický průměr naměřených hodnot je vhodným bodovým odhadem parametru $p$ alternativního rozdělení, což je pravděpodobnost, že náhodně vybraný student na otázku odpoví správně.

Detekce odlehlých hodnot pro možnost dalšího zpracování dat proběhla metodou vnitřních hradeb a následně byla bližze analyzována Dean-Dixonovým testem. $\mathrm{V}$ případě následné induktivní analýzy tak nedošlo k žádnému možnému zkreslení. Vzhledem k typu nástroje byla spočítána reliabilita prostřednictvím koeficientu Cronbach $\alpha$ (Cronbach, 1951; McGartland Rubio, 2005), přičemž byla zjištěna hodnota $\alpha_{C}=0,81$ značící akceptovatelnou hodnotu vnitřní konzistence nástroje (Tavakol \& Dennick, 2011). Vlastní induktivní analýza byla provedena na pětiprocentní hladině významnosti. Vzhledem $\mathrm{k}$ charakteru dat nebylo možné využít jednotného statistického aparátu. Jednotlivé výpočetní techniky jsou pak dále diskutovány vždy u konkrétní testované oblasti. 


\section{VÝSLEDKY}

Celková úspěšnost při řešení Lawsonova testu VM studentů učitelství pro 1. stupeň ZŠ dosahovala 30 \%. Lze tedy usuzovat, že test byl pro studenty relativně obtížný (tab. 1).

Tab. 1: Pravděpodobnost správné odpovědi na položky z dané oblasti

\begin{tabular}{lc}
\hline Sledovaná oblast & Průměrná úspěšnost \\
\hline zachování hmotnosti & $87 \%$ \\
\hline zachování vytlačeného objemu & $42 \%$ \\
\hline poměr & $16 \%$ \\
\hline identifikace a řízení změny & $21 \%$ \\
\hline pravděpodobnost & $22 \%$ \\
\hline korelace & $27 \%$ \\
\hline kombinační myšlení, obsahující prvky ze všech předchozích oblastí & $24 \%$ \\
\hline
\end{tabular}

Z výsledků je patrná nevyrovnanost průměrné úspěšnosti v jednotlivých oblastech testu. Velmi výrazně se liší úspěšnost v oblasti zachování hmotnosti, v níž byli studenti nejúspěšnější.

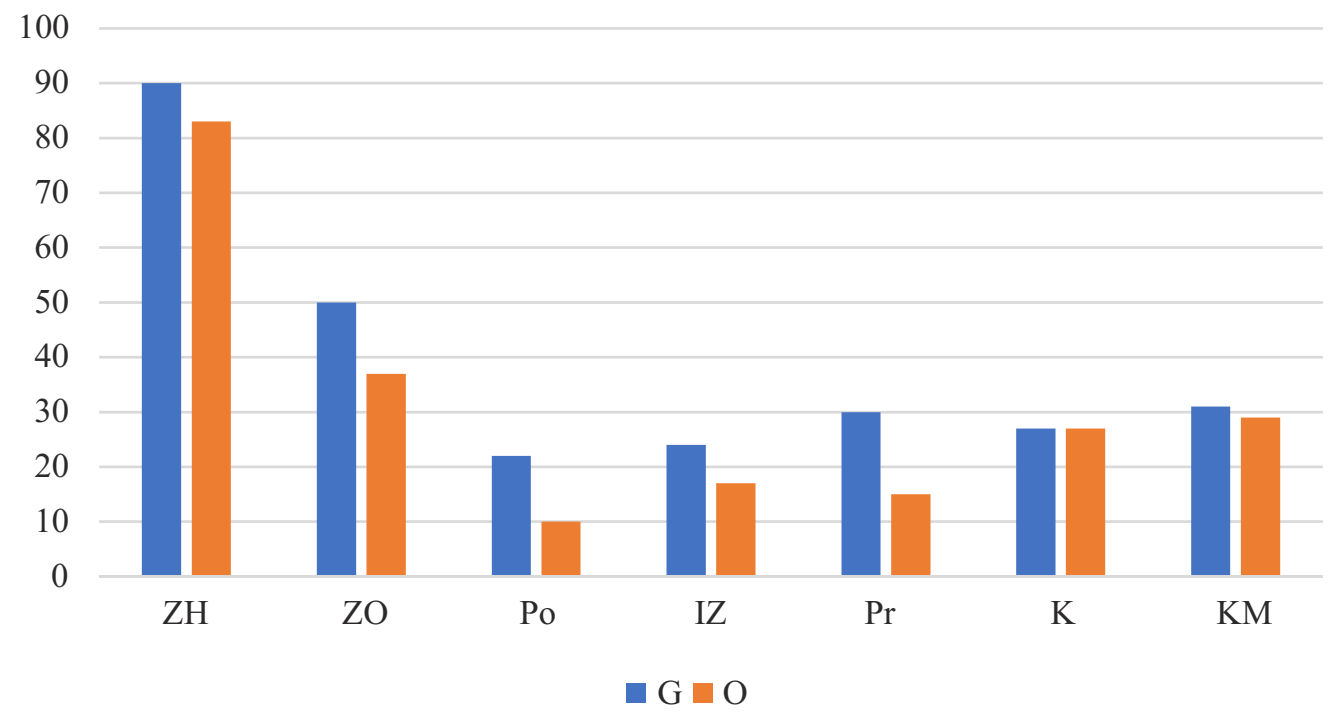

ZH - zachování hmotnosti, ZO - zachování objemu, Po - poměr, IZ - identifikace a řízení změny, $\mathrm{Pr}$ - pravděpodobnost, $\mathrm{K}$ - korelace, KM - kombinační myšlení, $\mathrm{G}$ - vystudované gymnasium, $\mathrm{O}$ - vystudovaná jiná střední škola

Obr. 2: Průměrná úspěšnost v jednotlivých oblastech testu

Porovnáním studentů gymnázií $(\mathrm{G})$ a studentů z ostatních středních škol $(\mathrm{O})$ zjištujeme, že studenti, kteří přišli na VŠ z gymnázií, byli úspěšnější, a to ve všech částech testu VM. Níže v části zaměřené na induktivní analýzu je ověřeno, zda je tento rozdíl statisticky významný.

Konkrétní výsledky úspěšnosti testu VM, absolutní přesnosti a bias indexu v jednotlivých testovaných oblastech zvlášt pro studenty gymnázií a studenty z ostatních středních škol jsou zaznamenány v tab. 2. Statistické veličiny uváděné ve výzkumné části práce jsou používány ve shodě s českou odbornou statistickou literaturou (Hendl, 2012). 
Tab. 2: Výsledky testu VM, indexu absolutní přesnosti a bias indexu

\begin{tabular}{cccccccccc}
\hline & Skola & ZH & ZO & Po & IZ & Pr & K & KM & Celkem \\
\hline \multirow{2}{*}{$\varnothing$} & $\mathrm{G}$ & 0,90 & 0,50 & 0,22 & 0,24 & 0,30 & 0,27 & 0,31 & 4,35 \\
\cline { 2 - 9 } & $\mathrm{O}$ & 0,83 & 0,37 & 0,10 & 0,17 & 0,15 & 0,27 & 0,29 & 3,35 \\
\hline \multirow{2}{*}{ Med } & $\mathrm{G}$ & 1,00 & 0,50 & 0,00 & 0,33 & 0,00 & 0,00 & 0,33 & 4,00 \\
\cline { 2 - 9 } & $\mathrm{O}$ & 1,00 & 0,00 & 0,00 & 0,00 & 0,00 & 0,00 & 0,33 & 3,00 \\
\hline \multirow{2}{*}{$\mathrm{AP}$} & $\mathrm{G}$ & 0,12 & 0,34 & 0,40 & 0,27 & 0,36 & 0,36 & 0,26 & 0,31 \\
\cline { 2 - 9 } & $\mathrm{O}$ & 0,19 & 0,35 & 0,41 & 0,25 & 0,30 & 0,33 & 0,23 & 0,29 \\
\hline \multirow{2}{*}{$\mathrm{B}$} & $\mathrm{G}$ & $-0,06$ & 0,31 & 0,46 & 0,35 & 0,28 & 0,35 & 0,08 & 0,27 \\
\cline { 2 - 9 } & $\mathrm{O}$ & $-0,11$ & 0,33 & 0,51 & 0,29 & 0,31 & 0,23 & 0,08 & 0,26 \\
\hline
\end{tabular}

ZH - zachování hmotnosti, ZO - zachování objemu, Po - poměr, IZ - identifikace a řízení změny, Pr - pravděpodobnost, $\mathrm{K}$ - korelace, KM - kombinační myšlení, G - vystudované gymnasium, O - vystudovaná jiná střední škola, $\varnothing$ - průměrná úspěšnost v jednotlivých položkách testu VM, Med - medián výsledků testu vědeckého myšlení, AP - absolutní př̀snost, $\mathrm{B}$ - bias index

Zjištěné hodnoty absolutní přesnosti v porovnání s vlastní úspěšností ukazují, že respondenti s větší přesností odhadovali svůj výkon u úloh, v nichž byli úspěšní (zejm. oblast $\mathrm{ZH}$ ). Jediná otázka, na kterou dokázala správně odpovědět většina studentů, se týkala zachování hmotnosti. Na základě analýzy soudů jistoty bylo zjištěno, že se zároveň jedná o otázku, s jejíž odpovědí si byli studenti nejvíce jisti. Objevuje se zde i jediný případ záporné hodnoty biasu, a to jak u studentů, kteří studovali gymnázium, tak u těch, kteří studovali jinou střední školu. V ostatních případech vykazuje bias kladnou hodnotu, která poukazuje na skutečnost, že se studenti spíše přeceňují ve své schopnosti vědeckého myšlení. Znamená to tedy, že si nejsou plně vědomi svých nedostatků v této oblasti. Celkově tedy pozorujeme, že úroveň vědeckého myšlení je nízká a nepřesnost v sebehodnocení vysoká.

\section{INDUKTIVNÍ AVALÝZA}

V rámci induktivní analýzy byl testován faktor věku, kdy studenti dosahovali věku 19 až 25 let, avšak nedošlo k verifikaci hypotézy o závislosti věku jako determinujícího faktoru. S ohledem na malý počet mužů ve vzorku nebyl zkoumán faktor pohlaví.

Vzhledem k charakteru dat byl pro porovnání VM žáků gymnázií a ostatních středních škol využit Mann-Whitney U test. Testování proběhlo oproti nulové hypotéze, která vychází z předpokladu, že mediány hodnot jsou si rovny. Získané hodnoty p-level jsou shrnuty v tab. 3 .

Tab. 3: Závislost druhu studované SS̆ na výsledek v testu VM, absolutní přesnost a bias

\begin{tabular}{lcccccccc}
\hline $\begin{array}{l}\text { Sledovaná } \\
\text { oblast }\end{array}$ & ZH & ZO & Po & IZ & Pr & K & KM & Celek \\
\hline $\begin{array}{l}\text { Vědecké } \\
\text { myšlení }\end{array}$ & $p=0,30$ & $p=0,16$ & $p=0,01$ & $p=0,25$ & $p=0,02$ & $p=0,99$ & $p=0,91$ & $p=0,01$ \\
\hline $\begin{array}{l}\text { Absolutní } \\
\text { presnost }\end{array}$ & $p=0,01$ & $p=0,55$ & $p=0,89$ & $p=0,62$ & $p=0,30$ & $p=0,52$ & $p=0,71$ & $p=0,68$ \\
\hline Bias & $p=0,19$ & $p=0,81$ & $p=0,45$ & $p=0,43$ & $p=0,74$ & $p=0,18$ & $p=0,60$ & $p=0,69$ \\
\hline
\end{tabular}

ZH - zachování hmotnosti, ZO - zachování objemu, Po - poměr, IZ - identifikace a řízení změny, $\mathrm{Pr}$ - pravděpodobnost, $\mathrm{K}$ - korelace, KM - kombinační myšlení 
Na základě hodnot $p$-level je možné se domnívat, že k zamítnutí nulové hypotézy dojde zejména $\mathrm{v}$ př́padě, kdy analyzujeme daný nástroj (test VM) jako celek a nezaměřujeme se na jeho dílčí aspekty. V tomto př́padě je možné hypotézu o shodných mediánech (vzhledem k neparametrickému typu dat) na obou typech škol zamítnout na jednoprocentní hladině významnosti $(p<0,01)$ a tvrdit, že studenti gymnázií dosahují lepších výsledků při testování vědeckého myšlení oproti studentům z jiných středních škol. Pro potřeby ověření závislosti skutečného výkonu v testu se sebehodnocením jedince charakterizovaným hodnotou indexu absolutní přesnosti byl využit výpočet Spearmanova koeficientu pořadové korelace (Spearman, 1904). Výsledky jsou zaznamenány v tab. 4.

Tab. 4: Korelace výsledků testu VM a indexu absolutní přesnosti

\begin{tabular}{lcccccccc}
\hline $\begin{array}{l}\text { Sledovaná } \\
\text { oblast }\end{array}$ & ZH & ZO & Po & IZ & Pr & K & KM & Celek \\
\hline $\begin{array}{l}\text { Absolutní } \\
\text { př́esnost }\end{array}$ & $-0,53^{* *}$ & $-0,72^{* *}$ & $-0,25^{* *}$ & $-0,21^{*}$ & 0,01 & $-0,22^{*}$ & $0,55^{* *}$ & $-0,16$ \\
\hline
\end{tabular}

* pětiprocentní hladina významnosti, ** jednoprocentní hladina významnosti, tučně vyznačené hodnoty znamenají, že výsledek je také věcně (prakticky) významný. ZH - zachování hmotnosti, ZO - zachování objemu, Po - poměr, IZ - identifikace a řízení změny, Pr - pravděpodobnost, $\mathrm{K}$ - korelace, KM - kombinační myšlení

U absolutní přesnosti bylo možné zamítnout $\mathrm{H}_{0}$ o nulovém korelačním koeficientu pouze u oblastí ZH, ZO, Po, a KM. Na pětiprocentní hladině významnosti pak také u oblasti IZ a K. Hodnota korelačního koeficientu je téměř vždy záporná, a proto ji lze tedy v př́padě absolutní přesnosti interpretovat tak, že čím úspěšnější byli studenti $\mathrm{v}$ testu VM, tím byli ve svých odhadech o vlastním výkonu více přesní (snižovala se hodnota AP - bližila se k nule).

\section{DisKuse}

$\mathrm{V}$ předloženém textu byla nastíněna možnost měřit úrovně VM studentů pro 1. stupeň ZŠ. Respondenti v testu VM dosáhli nízkých výsledků, nebot průměrná úspěšnost činila $30 \%$, zatímco při výzkumu, který prováděl Bao a kol. (2009b) dosahovala úspěšnost 70 \%. Takto vysoký rozdíl může být způsoben tím, že Bao se svým kolektivem zkoumal studenty technicky zaměřených oborů. Moore a Rubb (2012) však pozorovali VM i u studentů jiných než technických nebo přírodovědných oborů, v nichž úspěšnost v testu VM dosahovala u jejich respondentů $54 \%$, což je mnohem více než u námi pozorovaných studentio. Dykstra (2011) poukazuje na fakt, že ačkoli je Lawsonův test zasazen do přírodovědného kontextu, není $\mathrm{k}$ jeho úspěšnému řešení zapotřebí znalostí z této oblasti, i tak to však může některé respondenty ovlivnit a lze tedy předpokládat, že myšlení studentů je na vyšší úrovni, jen jej nejsou schopni využít $\mathrm{v}$ př́ŕrodovědném kontextu. Podíváme-li se podrobně na jednotlivé části testu, dosahovali studenti výrazně vyšších výsledků v oblasti ZH (87 \%). Tento trend je ve shodě s podobnými výzkumy (Ding, 2013; Moore \& Rubb, 2012).

Dále byla ověřena spojitost mezi úrovní vědeckého myšlení a druhem studované střední školy. Dle očekávání dosahovali respondenti z gymnázií vyšších výsledků ve všech částech testu než studenti, kteří studovali jinou střední školu. Statisticky významný rozdíl byl však pouze v oblastech poměru, pravděpodobnosti a v testu jako celku. Moore a Rubb (2012) upozorňují, že v těchto oblastech se staví na matematických konceptech, jež jsou logicky pevnější u gymnaziálních žáků. 
Jak již bylo naznačeno v úvodu, není úroveň VM u žáků nikterak vysoká a zjištěné výsledky u vysokoškolských studentů vypovídají o tom, že VM není rozvíjeno ani na dalších stupních vzdělávání. Vysokoškolští studenti, budoucí učitelé žáků prvního stupně, tak budou stavěni do nelehké situace rozvíjet zpơsob myšlení, který jim samotným není vlastní. Vzniká tedy reálná hrozba toho, že ani další generace žáků nebude VM dotčena. Otázkou zůstává, jak tento trend zastavit. Prostor, který by skýtal vhodné prostředí pro rozvoj VM studentů, poskytují př́rodovědně orientované předměty, jež jsou součástí studia učitelství pro první stupeň ZŠ. Pro rozvoj VM je jistě zapotřebí mnoho názorných demonstrací, především vlastní zkušenosti studentů s navrhováním a provedením experimentů a s následnou analýzou jejich výsledků, což však nebude možné bez patřičného vybavení ani vhodně zvolené vyučovací metody.

Pozornost byla rovněž věnována fenoménu metakognitivního monitorování indikovaného skrze diskrepanci mezi hodnotou subjektivního odhadu míry jistoty správnosti odpovědi a skutečně prokázaným výkonem. Výsledky můžeme diferencovat do základních čtyř rovin:

Za prvé, a to kromě jediné oblasti VM, se ukázala signifikantní korelace mezi rostoucí výkonností a hodnotou absolutní přesnosti (čím vyšší výkonnost, tím více se blíží hodnota absolutní přesnosti k nule), což koresponduje s existujícími výzkumy, které prokazují, že míra přesnosti absolutní přesnosti př́mo souvisí s úspěchem studentů v daném předmětu či oblasti (např. Kruger \& Dunning, 1999; Hacker et al., 2000).

Za druhé výzkum naznačil poměrně významné nadhodnocení studentů. Podle odborné literatury dochází k nadhodnocení participujících subjektů ve čtyřech hlavních situacích: (a) Hard-easy effect popisuje situaci, v níž nadhodnocování nastává obvykle u obtížných položek a podhodnocení u lehkých položek testu (Nietfled et al., 2005). V oblasti VM (ZH), kde studenti skórovali s průměrem $87 \%$, můžeme jako u jediné z oblastí pozorovat mírné podcenění. U všech ostatních oblastí VM je patrné jasné nadhodnocení vlastní výkonnosti. (b) Nadhodnocení (zejm. u výkonnostně slabších studentů) se rovněž děje z důvodu nedostatku znalostí, které omezují možnosti stanovit adekvátní standard (kritérium) pro hodnocení vlastního výkonu ${ }^{4}$. (c) Dalším důvodem výrazného nadhodnocení může být vlastní aktivita respondenta při snaze porozumět testové položce (úsilí o její zodpovězení vyčerpává kognitivní prostředky natolik, že student již nedisponuje dostatečnou kapacitou pro metakognitivní monitorování (Dunning, Johnson, Ehrlinger \& Kruger, 2003). (d) Závěrečnou situací, při níž dochází k přecenění vlastní výkonnosti, je přání či přesvědčení studenta, že jeho úsilí má značný efekt na reálnou výkonnost (Schneider, 1999). Můžeme se pouze domnívat, která ze čtyř situací (či jejich kombinace) nastala v našem výzkumu. Spíše vylučujeme vysvětlení (c) a (d), které je typické pro žáky mladšího věku, a vyzdvihujeme vysvětlení (a) a (b).

Za třetí se neprojevil signifikantní rozdíl v absolutní přesnosti mezi skupinou „gymnazistů“ a „ostatních studentů“ (nastal pouze v oblasti ZH; nikoliv pro celý test VM). Přestože „gymnazisté“ v testu VM skórovali celkově signifikantněji lépe, nastává tak užitek ze zapojení metakognitivních procesů v případě, jedná-li se o adekvátně náročné úlohy (Prinsem et al., 2006; Neuenhaus, 2011). Je-li úspěšnost řešených oblastí (až na výjimky) pod hranicí 30 \%, je nasnadě, že se nejedná o přiměře-

\footnotetext{
${ }^{4}$ Též jako tzv. iluze kompetence. V zahraniční literatuře jako: illusion of competence (Koriat \& Bjork, 2005), unskilled but unaware effect (Hacker, Bol \& Keener, 2008), Dunning-Kruger effect (Kruger \& Dunning, 1999).
} 
nou náročnost úloh. Z toho důvodu není ani překvapivé, že se neobjevily signifikantní rozdíly v úrovni absolutní přesnosti.

V souvislosti s rovinou dva a tři při interpretaci výsledků metakognitivního monitorování je oprávněné se domnívat, že by přesnost posouzení vlastního výkonu byla vyšší (bližila se $\mathrm{k}$ nule) u testu, který by pro studenty nebyl tolik náročný (adekvátně náročný, čímž by došlo k „blokaci“ hard-easy efektu).

Za čtvrté se index absolutní přesnosti pohyboval v rozmezí od 0,12 po 0,40 s mediánem 0,29. Tato hodnota značí vysokou míru nepřesnosti a potvrzuje obecný předpoklad, že ani v dospělosti nedosahuje úroveň metakognitivního monitorování adekvátní úrovně (Lai, 2011). V případě našeho výzkumu se však jedná o poměrně alarmující zjištění, jelikož participanti našeho výzkumu budou osoby, které budou (by měly) metakognitivní schopnosti žáků rozvíjet. Nastává smutný paradox, že osoba v roli učitele, a to bez adekvátní úrovně metakognitivního monitorování, bude (by měla) metakognitivní potenciál žáka rozvíjet (včetně posouzení úrovně žákova nadhodnocení/podhodnocení). Je to vůbec v praxi možné?

\section{ZÁvĚR}

V předložené studii jsme se zabývali vědeckým myšlením a metakognicí, konkrétně metakognitivním monitorováním studentů oboru učitelství pro 1. stupeň ZŠ. Vědecké myšlení bylo zjištováno na základě Lawsonova testu vědeckého myšlení, který byl doplněn o ratingové škály, jež umožnily vyhodnotit úroveň metakognitivního monitorování, a to ve formě hodnot indexu absolutní přesnosti a bias indexu. Zjištěné výsledky poukazují na nízkou úroveň vědeckého myšlení sledovaných studentů. U samotných budoucích pedagogů není tedy tento zpo̊sob myšlení plně rozvinut, a tudíž lze předpokládat, že pro ně bude v praxi náročné, ne-li nemožné, pomoci žákům VM rozvíjet. Při analýze se sice objevily rozdíly mezi studenty, kteří dříve studovali gymnázium, a studenty, kteří absolvovali jinou střední školu, a to ve prospěch studentů z gymnázia (dosáhli celkově lepších výsledků), avšak tento rozdíl nebyl statisticky významný pro všechny dílčí části testu. K tomuto závěru je možné dojít pouze za předpokladu, že bude test hodnocen jako celek.

Vysokých hodnot, značících vysokou nepřesnost, dosahovaly výsledné hodnoty absolutní přesnosti (indikátor úrovně metakognitivního monitorování). Rozdíly mezi studenty „gymnazisty“ a „ostatními“ v oblasti absolutní přesnosti nebyly prokázány. Benefit ze zapojení metakognitivních procesů nastává v momentě, kdy student řeší adekvátně náročnou úlohu. Je-li celková úspěšnost $30 \%$, lze se zřejmě oprávněně domnívat, že se nejednalo o adekvátně náročné úlohy. Hodnoty indexu bias poukazovaly na tendenci respondentů se nadhodnocovat. Potvrzena byla korelace mezi absolutní přesností a výkonností v testu VM.

Jak prakticky skloubit oba přístupy, aby docházelo k maximálnímu rozvoji VM a metakognitivního monitorování žáků? Za vhodný přístup považujeme např. badatelsky orientovanou výuku (dále jen BOV) (Bao et al., 2009a; Lawson, 1995; Benford \& Lawson, 2001; Gerber, Cavallo \& Marek, 2001), kterou Linn, Davis a Bell (2004: s. 15) definují jako:

Intencionální proces formulování problémů, kritického experimentování, rozlišování alternativ, plánování výzkumu, ověřování domněnek, vyhledávání informací, diskutování s vrstevníky, zjištóování informací od odborníků a formování koherentních argumentů. 
BOV tak poskytuje př́hodné podmínky jak pro rozvoj VM, tak i pro rozvoj metakognitivního potenciálu žáka, včetně metakognitivního monitorování. Jiný přístup k rozvoji VM přináší Hejnová a Hejna (2016), kteří ve svém článku předkládají návrhy aktivit podporující rozvoj VM, přičemž se však nejedná o komplexní rozvoj, jak je tomu při zmiňované BOV, nebot autoři uvádějí př́islušné činnosti zaměřené na jednotlivé dovednosti podporující VM.

Výsledky výzkumu vyvolávají celou řadu otázek a námětů pro navazující výzkumy, jako např.: „Jakého skóre VM a úrovně metakognitivního monitorování by dosáhli učitelé s mnohaletou praxí, nebo pedagogové na druhém a třetím stupni? Existuje ve vysokoškolských kurikulech kurz, který rozvíjí studentovo VM a metakognitivní potenciál a zároveň učí, jak oba fenomény u žáků rozvíjet?" Zjištění předložená $\mathrm{v}$ této studii považujeme za prvotní impulz otevírající cesty pro další navazující výzkumná směřování.

\section{PODĚKOVÁNí}

Př́spěvek vznikl díky financování v rámci specifického výzkumu, projekt Studentské grantové soutěže UJEP-SGS-172-03-10.

\section{LITERATURA}

Bandura, A. \& Schunk, D. H. (1981). Cultivating competence, self-efficacy, and intrinsic interest through proximal self-motivation. Journal of Personality and Social Psychology, $41(3), 586-598$.

Benford, R. \& Lawson, A.E. (2001). Relationships between effective inquiry use and the development of scientific reasoning skills in college biology labs. Arlington, VA: National Science Foundation

Bao, L., Cai, T., Koenig, K., Fang, K., Han, J., Wang, J., Wang, Y. et al. (2009a). Learning and scientific reasoning. Science, 323(5914), 586-587.

Bao, L., Fang, K., Cai, T., Wang, J., Yang, L., Cui, L., Luo, Y. et al. (2009b). Learning of content knowledge and development of scientific reasoning ability: A cross culture comparison. American Journal of Physics, 77(12), 1118-1123.

Bao, L. \& Koenig, K. (2012). TI21: A technology enhanced inquiry framework for developing and assessing 21st century skills.

Dostupné z http://www.istarassessment.org/ti21/

Beneš, P. (1999). Reálné modelové experimenty ve výuce chemie. Praha: UK PedF.

Beneš, P., Rusek, M. \& Kudrna, T. (2015). Tradice a současný stav pomůckového zabezpečení edukačního chemického experimentu v České republice. Chemické Listy, 109(2), 159-162.

Blažek, R. \& Př́íhodová, S. (2016). Mezinárodní šetření PISA 2015: národní zpráva: př́rodovědná gramotnost. Praha: Česká školní inspekce.

Bol, L. \& Hacker, D. J. (2012, June 19). Calibration research: Where do we go from here? Dostupné z http://journal.frontiersin.org/article/10.3389/fpsyg.2012.00229/full

Coletta, V.P. \& Phillips, J. A. (2005). Interpreting FCI scores: Normalized gain, preinstruction scores, and scientific reasoning ability. American Journal of Physics, $73(12), 1172-1182$. 
Cronbach, L. J. (1951). Coefficient Alpha and the internal structure of tests. Psychometrika, 16(3), 297-334.

Dejonckheere, P. J., Van De Keere, K. \& Mestdagh, N. (2009). Training the scientific thinking circle in pre-and primary school children. The Journal of Educational Research, 103(1), 1-16.

Ding, L. (2013). Detecting progression of scientific reasoning among university science and engineering students. In Physics Education Research Conference 2013 (125-128). Portland, OR: AAPT.

Dunning, D., Johnson, K., Ehrlinger, J. \& Kruger, J. (2003). Why people fail to recognize their own incompetence. Current Directions in Psychological Science, 12, 83-87.

Dykstra Jr, D. I. (2011). Výuka fyziky a rozvoj myšlení. Scientia in educatione, 2(2), 59-75.

Gerber, B. L., Cavallo, A. M. \& Marek, E. A. (2001). Relationships among informal learning environments, teaching procedures and scientific reasoning ability. International Journal of Science Education, 23(5), 535-549.

Gilbert, J. (2005) Catching the knowledge wave: the knowledge society and the future of education. Wellington, New Zealand: NZCER Press.

Hacker, D. J., Bol, L., Horgan, D. D. \& Rakow, E. A. (2000). Test prediction and performance in a classroom context. Journal of Educational Psychology, 92(1), 160-170.

Hejnová, E. \& Hejna, D. (2016). Rozvoj vědeckého myšlení žáků prostřednictvím př́rodovědného vzdělávání. Scientia in educatione, 7(2), 2-17.

Hendl, J. (2012). Přehled statistických metod. Praha: Portál.

Holyoak, K. J. \& Morrison, R. G. (Eds.) (2005). The Cambridge handbook of thinking and reasoning. Cambridge University Press.

Hilton, M. (2008). Skills for work in the 21st century: what does the research tell us? The Academy of Management Perspectives, 22(4), 63-78.

Chytrý, V. (2015) Logika, hry a myšlení. 1. vyd. Ústí nad Labem: Univerzita J. E. Purkyně v Ústí nad Labem.

Chytrý, V., Pešout, O. \& Říčan, J. (2014). Preference metakognitivních strategii na pozadí úkolových situací v matematice u žáků druhého stupně Zঙ̆. Ústí nad Labem: Univerzita J. E. Purkyně v Ústí nad Labem.

Jang, H. (2016). Identifying 21st century STEM competencies using workplace data. Journal of Science Education and Technology, 25(2), 284-301.

Janoušková, S., Hubáčková, L., Pumpr, V. \& Maršák, J. (2014). Přírodovědná gramotnost v preprimárním a raném období primárního vzdělávání jako prostředek zvýšení zájmu o studium př́rodovědných a technických oborů. Scientia in educatione, $5(1), 36-49$.

Kruger, J. \& Dunning, D. (1999). Unskilled and unaware of it: How difficulties in recognizing one's own incompetence lead to inflated self-assessments. Journal of Personality and Social Psychology, 77(6), 1121-1134.

Kuhn, D. (2010). What is scientific thinking and how does it develop?. In U. Goswami (Ed.), The Wiley-Blackwell Handbook of Childhood Cognitive Development (2nd ed.) (497-523). Oxford: Wiley-Blackwell. 
Kuhn, D. \& Franklin, S. (2006). The second decade: What develops (and how). John Wiley \& Sons, Inc.

Kuhn, D. \& Pearsall, S. (2000). Developmental origins of scientific thinking. Journal of cognition and Development, 1(1), 113-129.

Lawson, A.E. (1995). Science teaching and the development of thinking. Belmont, CA: Wadsworth Publishing Company.

Lawson, A.E. (2000). Classroom test of scientific reasoning: Multiple choice version. Dostupné z http://www.public.asu.edu/ anton1/AssessArticles/Assessments/

Mathematics\%20Assessments/Scientific\%20Reasoning\%20Test.pdf

Linn, M. C., Davis, E. A. \& Bell, P. (2004). Internet environments for science education. Mahwah, New Jersey, USA: Lawrence Erlbaum Associates, Inc., Publishers.

Maki, R.H., Shields, M., Wheeler, A.E. \& Zacchilli, T. L. (2005). Individual differences in absolute and relative metacomprehension accuracy. Journal of Educational Psychology, 97, 723-731.

Moore, N., O'Donnell, J. \& Poirier, D. (2012). Using cognitive acceleration materials to develop pre-service teachers' reasoning and pedagogical expertise. In Advancing the STEM Agenda in Education, University of Wisconsin.

Moore, J. C. \& Rubbo, L. J. (2012). Scientific reasoning abilities of nonscience majors in physics-based courses. Physical Review Special Topics-Physics Education Research, 8(1), 010106.

McGartland Rubio, D. (2005). Alpha reliability. In K. Kempf-Leonard (Ed.), Encyclopedia of social measurement (59-63). Elsveir.

Neuenhaus, N. (2011). Metakognition und leistung: Eine längsschnittuntersuchung in den bereichen lesen und Englisch bei schülerinnen und schülern der fünften und sechsten jahrgangsstufe [Doctoral dissertation]. Universität Otto-Friedrich, Bamberg, Germany. Retrieved from http://opus4.kobv.de/opus4/bamberg/frontdoor/deliver/index/docId/ 327/file/DissNeuenhausseA2.pdf

Nietfeld, J. L., Cao, L. \& Osborne, J. W. (2005). Metacognitive monitoring accuracy and student performance in the postsecondary classroom. The Journal of Experimental Educational, 74, 7-28.

Osborne, J. (2013). The 21st century challenge for science education: Assessing scientific reasoning. Thinking Skills and Creativity, 10, 265-279.

Osborne, J. \& Ratcliffe, M. (2002). Developing effective methods of assessing ideas and evidence. School Science Review, 83(305), 113-123.

Prins, F. J., Veenman, M. V. J. \& Elshout, J. J. (2006). The impact of interllectual ability and metacognition on learning: New support for the threshold of problematicity theory. Learning and Instruction, 16, 374-387.

Říčan, J. (2016). Metakognice a metakognitivni strategie jako teoretické a výzkumné konstrukty a jejich uplatnění v moderní pedagogické praxi. Most: Hněvín.

Schraw, G. (1998). Promoting general metacognitive awereness. Instructional Science, 26(1-2), 113-125.

Spearman, C. (1904). The proof and measurement of association between two things. The American Journal of Psychology, 15(1), 72-101.

Tavakol, M. \& Dennick, R. (2011). Making sense of Cronbach's alpha. International Journal of Medical Education, 2011(2), 53-55. 
Trna, J. (2013). Fyzika: Záhadná setrvačnost těles v jednoduchých experimentech. In T. Janík, J. Slavík, V. Mužík, J. Trna, T. Janko, V. Lokajíčková, J. Lukavský, E. Minaříková, Z. Šalamounová, E. Šebestová, N. Vondrová \& P. Zlatníček (Eds.), Kvalita (ve) vzdělávání: obsahově zaměřený přsistup ke zkoumáni a zlepšováni výuky (284-293). Brno: Masarykova Univerzita.

Tomášek, V., Basl, J. \& Janoušková, S. (2016). Mezinárodni šetření TIMSS 2015:

Národní zpráva. Prague, Czechia: Česká školní inspekce. Retrieved from www.csicr.cz $/$ html/timss $/$ html5/index.html?\&locale $=$ CSY\&pn $=3$

Windschitl, M. (2004). Folk theories of "inquiry": How preservice teachers reproduce the discourse and practices of an atheoretical scientific method. Journal of Research in Science Teaching, 41(5), 481-512.

Winne, P. H. \& Hadwin, A. (1998). Studying as selfregulated learning. In D. J. Hacker, J. Dunlosky \& A. C. Graesser (Eds.), Metacognition in educational theory and practice (277-304). Mahwah, NJ: Erlbaum.

Zimmerman, C. (2007). The development of scientific thinking skills in elementary and middle school. Developmental Review, 27, 172-223.

AlEnA NovÁKovÁ, alena.novakova.ph@gmail.com

Vlastimil ChYTRÝ, vlastimil.chytry@ujep.cz

JAROSLAV Ř́́ČAn, Jaroslav.Rican@ujep.cz

Univerzita Jana Evangelisty Purkyně v Ústí nad Labem, Pedagogická fakulta

Katedra preprimárního a primárního vzdělávání

Pasteurova 1, 400 96, Ústí nad Labem, Česká republika 